\title{
CO-BRINE-ROCK INTERACTIONS AS A RESULT OF LONG TERM EXPERIMENT ONTO ROCK SAMPLES FROM CHABOWO ANTICLINE, POLAND
}

\section{Magdalena WDOWIN ${ }^{1}$, Radosław TARKOWSKI ${ }^{1}$ \& Maciej MANECKI ${ }^{2}$}

\author{
${ }^{1}$ Mineral and Energy Economy Research Institute of the Polish Academy of Sciences; \\ ul. Wybickiego 7, 31-261 Krakow; \\ e-mail:mwdowin@gmail.com,tarkowski@min-pan.krakow.pl \\ ${ }^{2}$ AGH University of Science and Technologies, Faculty of Geology, \\ Geophysics and Environmental Protection; \\ al. Mickiewicza 30, 30-059 Krakow; \\ e-mail: gpmmanec@cyf-kr.edu.pl
}

\begin{abstract}
The presented work concerns investigations of $\mathrm{CO}_{2}$-brine-rock interactions conducted over a period of 20-months. Experiments were carried out at laboratory scale with the use of equipment specifically designed for this purpose. Research materials (reservoir and cap rocks) were taken from the Chabowo 3 well located within Chabowo anticline. The experiments were carried out at room temperature (about $25^{\circ} \mathrm{C}$ ) and pressure about $6 \mathrm{MPa}$. For samples before and after the experiment a numerous investigations were carried out i.e. petrophysical (porosity, surface area, threshold diameter, average capillary, framework and bulk densities) and petrological-mineralogical characteristics. Also brine used for examination before and after experiment was analyzed (chemical analysis).

Petrophysical results have shown a significant decrease of porosity (from $17.0 \%$ to $7.5 \%$ ) and surface area (from $0.395 \mathrm{~m}^{2} / \mathrm{g}$ to $0.196 \mathrm{~m}^{2} / \mathrm{g}$ ) in case of sandstone. These changes are caused probably by crystallization of halite in pore spaces, because mineralogical analysis (XRD) has shown the presence of halite (3-5\% vol. in the rock) after experiment. More detailed results were obtained during mineralogical analyses of thin sections. These results have shown in sandstone samples a small increase of porosity and a small decrease of feldspar and cements (carbonate and clay) as well as matrix which suggests dissolution of these constituents. For claystone - after experiment XRD clay fraction has shown absence of clay minerals such as montmorillonite, which may also be caused by interaction between the rock, $\mathrm{CO}_{2}$ and brine. Dissolution of some minerals is evidenced by chemical analysis of brine where amounts of most tested ions increase after experiment for both sandstone and claystone.
\end{abstract}

Key words: $\mathrm{CO}_{2}$-brine-rock interactions, $\mathrm{CO}_{2}$ sequestration, petrophysical investigation, petrology-mineralogical characteristics, Chabowo anticline 


\section{INTRODUCTION}

Atmospheric carbon dioxide is thought the most important factor in driving recent anthropogenic global warming (IPCC 2007), and its amount in atmosphere further increases. Geological sequestration of $\mathrm{CO}_{2}$ in deep formations (e.g., saline aquifers, oil and gas reservoirs and coalbeds) has drawn increasing consideration as a promising option to mitigate the adverse impacts of climate change (IPCC 2005). Deep saline aquifers constitute the largest storage potential of all the geological $\mathrm{CO}_{2}$ storage (Birkholzer \& Zhou 2009) and saline basins have proved to be the most promising choice for sequestration of $\mathrm{CO}_{2}$ to reduce its emissions into the atmosphere (Pang et al. 2013). Geological storage in saline aquifers is related to a complex process with multiple mechanisms responsible for carbon storage. The suitability of geological formations for $\mathrm{CO}_{2}$ storage shall be determined through evaluation and assessment of the storage site (Labus 2009). After injection of $\mathrm{CO}_{2}$ into saline aquifers, it may be trapped via one or more processes e.g.: solubility and mineral trapping. In hydrodynamic processes and solubility trapping, $\mathrm{CO}_{2}$ is converted into a fluid or aqueous solution (Soong et al. 2004) whereas in mineral trapping, it is stored permanently as stable carbonate minerals precipitating by a series of chemical reactions with dissolved metals in the saline aquifer (Gunter et al. 2000).

Once injected, carbon dioxide interacts with the host rocks and reservoir fluids: it dissolves in reservoir liquids (Muller et al. 2009, Zeidouni et al. 2009), reacts with minerals of the rock matrix (Gunter et al. 1993), and, if the sealing is not perfect, can leak into overlying lithologies (Gaus et al. 2005), or ultimately to the surface (Tarkowski \& Wdowin 2011).

Understanding the interaction processes between $\mathrm{CO}_{2}$, rock and reservoir fluids is important for optimizing the process of $\mathrm{CO}_{2}$ injection into underground reservoirs. Considering these phenomena during planning of $\mathrm{CO}_{2}$ storage projects reduces risks of gas leakage from the underground reservoir, and consequent failure of the storage operation (Wdowin et al. 2013, 2014).

Defined knowledge of the $\mathrm{CO}_{2}$-induced interactions between injected $\mathrm{CO}_{2}$, saline formation fluid and reservoir rocks and under reservoir conditions, as well of the resulting changes in the chemical and physical properties of the reservoir system is therefore a prerequisite for any secure operation of a storage site (Fischer et al. 2010).

This paper presents the results of petrophysical and petrological-mineralogical investigations of reservoir and cap rock in long term experiments of $\mathrm{CO}_{2}$-brine-rocks interactions. These investigations were made to assess the usefulness of the Chabowo anticline from the view point of geological sequestration of $\mathrm{CO}_{2}$.

\section{METHODS}

\section{Experiment}

The experiment was conducted in especially designed stainless steel reactors (with a volume of about $1.8 \mathrm{dm}^{3}$ ). The tested samples were placed on the Petri dishes in glass cylinders (reservoir rocks and cap rocks separately) positioned in the reactors, and inundated 
with artificially prepared brine so as not to come to direct contact with the rock and the walls of the reactor (Wdowin et al. 2013). The chemical composition of the brine corresponds to the brines from the Jurassic rocks (sandstones and claystones) of Chabowo region i.e. individual ions were as follows: $\mathrm{Cl}^{-}-50,700 \mathrm{mg} / \mathrm{l} \mathrm{SO}_{4}{ }^{2-}-728 \mathrm{mg} / \mathrm{l}, \mathrm{HCO}_{3}{ }^{-}-110 \mathrm{mg} / \mathrm{l}$, $\mathrm{Ca}^{2+}-1,178 \mathrm{mg} / 1, \mathrm{Mg}^{2+}-164 \mathrm{mg} / \mathrm{l}, \mathrm{Na}^{+}-29,500 \mathrm{mg} / 1, \mathrm{~K}^{+}-211 \mathrm{mg} / \mathrm{l}$.

A set of the closed reactors was connected with a $\mathrm{CO}_{2}$-containing cylinder. The duration of experiment was 20 months, at room temperature $\left(20-25^{\circ} \mathrm{C}\right)$ at the container-gas pressure (i.e. about $6 \mathrm{MPa}$ ).

\section{Petrophysical investigation}

In order to investigate the pore space structure, $\mathrm{Hg}$ porosimetric analysis was used. The analysis was performed using an AUTO PORE 9220 mercury porosimeter from Micromeritics. The principle of capillary pressure measurements consisted of injecting non-wetting liquid (mercury) into the rock samples under clearly defined pressures. The maximum pressure applied was 30,000 PSI, which allowed injecting mercury into the micropores of a minimum diameter of $9 \mathrm{~nm}$. During the measurements, the volume of mercury was determined, injected under increasing pressure into smaller and smaller pores in the pore space of the rock. The sizes (diameters) of pores into which mercury was injected, were calculated using the Washborne equation:

$$
D=(1 / p) y \cos \phi
$$

where:

$D$ - diameter of the pores,

$p$ - pressure used (according to pressure tables),

$\phi$ - mercury-rock contact angle,

$y$ - surface tension.

Based on the analysis of cumulative curves (i.e. capillary pressure curves), a number of parameters were calculated, characterising the pore space structure of the rock, including dynamic porosity, specific surface area, average capillary size and threshold diameter (threshold pressure).

\section{Petrology-mineralogical investigation}

Microscopic observations in transmitted light and planimetric analysis were performed with polarizing microscope JENALAB Karl Zeiss Jena, using the magnifications of: $2.5 \times 0.05 ; 10 \times 0.25 ; 50 \times 0.08$.

The scanning electron microcopy analysis was carried out using electron microscopy - FEI Quanta 250 FEG SEM equipped with a chemical composition analysis system based on energy dispersion scattering EDS-EDAX. 
X-ray diffraction analysis (XRD) was performed with powder X-ray diffractometer Philips X'Pert APD with goniometer PW 3020 and copper lamp as well graphite monochromator. Analysis was performed in the angular range of 5-65 $2 \Theta$. For the diffraction data processing the software Philips X'Pert was used. Identification of mineral phases was carried out based on the database JCPDS-ICDD. For the separated clay fraction the angular range of 5-35 $2 \Theta$ was applied. In accordance with the methodology of clay minerals study, for the separated clay fractions, the sedimented preparations were made, which were soaked in ethylene glycol by evaporation methods over a period of 12 hours at $60^{\circ} \mathrm{C}$ and then calcined at $560^{\circ} \mathrm{C}$ for one hour.

\section{STUDY AREA}

Research area constituted the Chabowo anticline (Fig. 1) located about $15 \mathrm{~km}$ on E-SE from Gryfino (NW Poland), formed on Gryfino-Chabowo-Choszczno swell. From the point o view of $\mathrm{CO}_{2}$ storage the most interesting seems to be a part of this structure composed of the Jurassic formation, $400 \mathrm{~m}$ in thickness and made up of sandstone, mudstone and claystone (Tarkowski 2010).

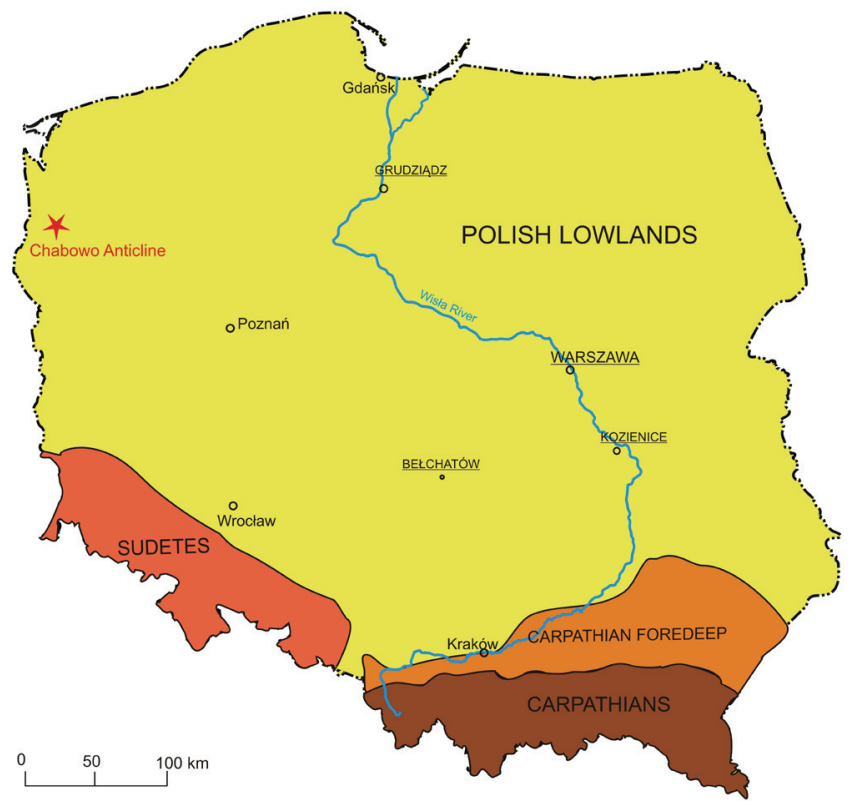

Fig. 1. Location map of Chabowo anticline as a potential side to $\mathrm{CO}_{2}$ storage

Potential reservoir rocks (sandstones) and sealing rocks (claystones) from various depth intervals were selected for experiments (Tab. 1). 
Table 1

Rock samples selected for investigation

\begin{tabular}{|c|c|c|c|}
\hline No. & Well & Depths [m] & Sort of sample \\
\hline 1 & Chabowo 3 & $1145-1146$ & claystone \\
\hline 2 & Chabowo 3 & $1240-1241$ & sandstone \\
\hline
\end{tabular}

\section{RESULTS}

\section{Petrophysical investigation}

Because claystone samples were destroyed after experiment the petrophysical investigations were carried out only for raw/original samples (i.e. before the experiment).

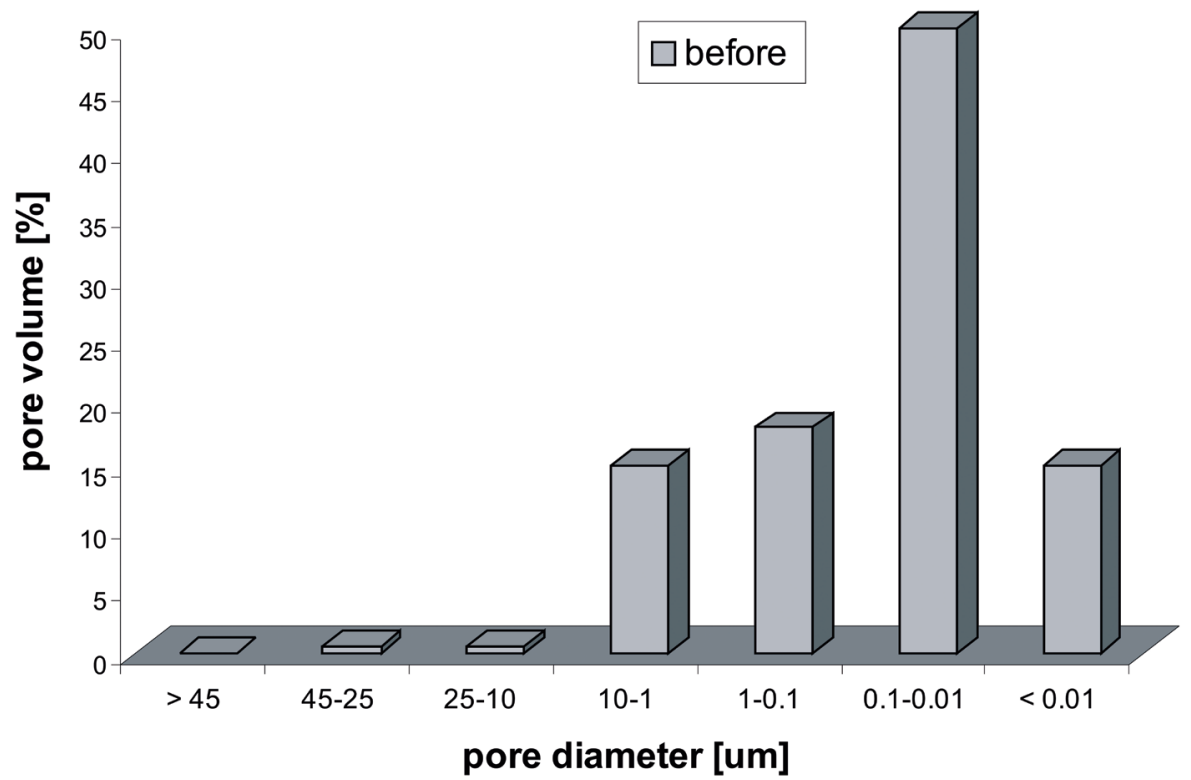

Fig. 2. Distribution of pore space before the experiment for claystone

\section{Cap rocks}

Petrophysical analyzes show that the studied cap rocks have higher surface area (an average of $5.908 \mathrm{~m}^{2} / \mathrm{g}$ ) than tested sandstone (Tab. 2). This rock has a threshold diameter of the order of $0.12 \mu \mathrm{m}$ and average capillary about $0.416 \mu \mathrm{m}$. The framework density is $2.5 \mathrm{~g} / \mathrm{cm}^{3}$ and bulk density amounts to $2.2 \mathrm{~g} / \mathrm{cm}^{3}$, respectively. The studied claystone has also 
a different pore space (Tab. 3, Fig. 2), where the predominant pore diameter is in the range of $0.10-0.01 \mu \mathrm{m}(50 \%)$. Due to the fact that petrophysical parameters have to be determined on solid rock, examinations after the experiment were not carried out, because the clay sample was split during experiment.

\section{Sandstones}

Petrophysical analysis (Tab. 2) showed that the tested sandstone (before the experiment) has low average surface area of $0.395 \mathrm{~m}^{2} / \mathrm{g}$ and porosity of $17 \%$. It is characterized by a diversity of pore space (Tab. 3, Fig. 3). Three ranges of pore diameter predominate, i.e. 25-10 $\mu \mathrm{m}$ (49\%), 10-1 $\mu \mathrm{m}(29 \%)$, and 1.0-0.1 $\mu \mathrm{m}(15 \%)$.

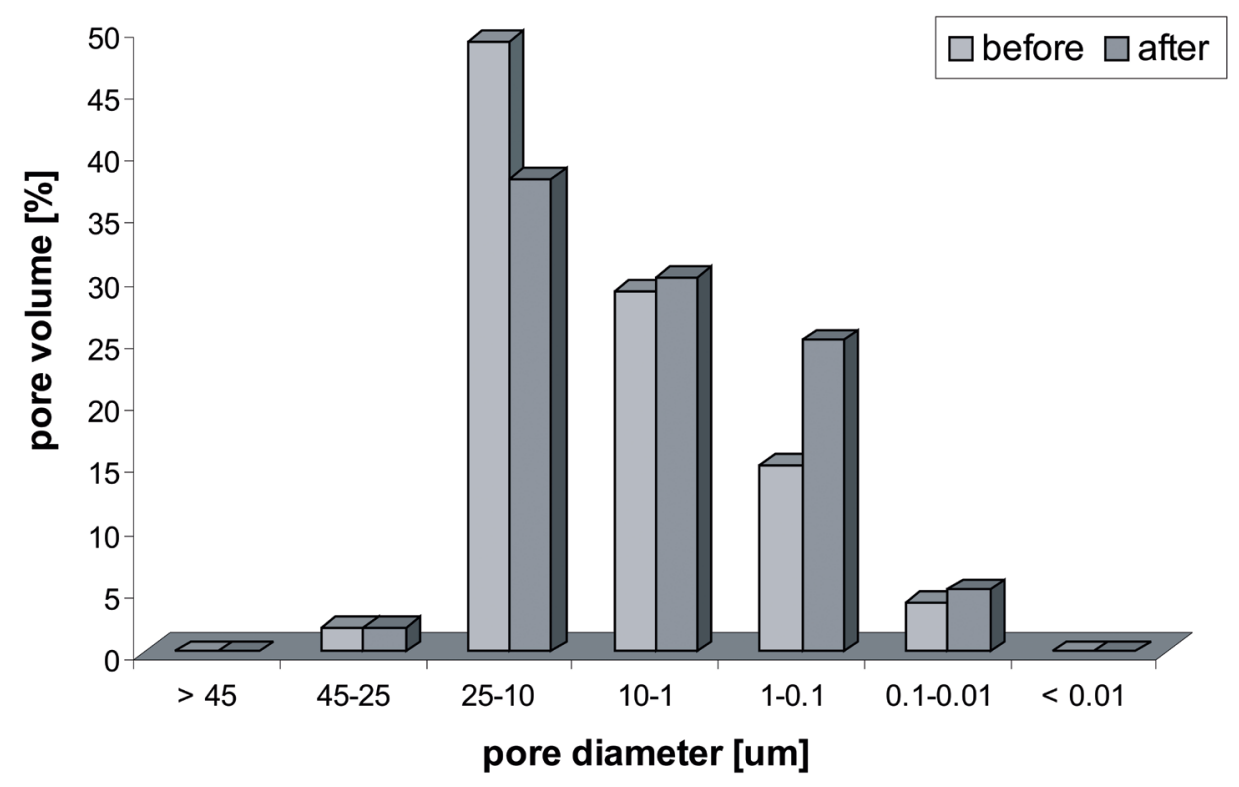

Fig. 3. Distribution of pore space before and after experiment for sandstone

The experiment had a significant impact on changing some of the petrophysical parameters of the studied sandstone (Tab. 2). A significant decrease of the porosity from $17.0 \%$ to $7.9 \%$ was observed. Increased framework density of $3.07 \mathrm{~g} / \mathrm{cm}^{3}$ to $3.36 \mathrm{~g} / \mathrm{cm}^{3}$ and a bulk density of $2.54 \mathrm{~g} / \mathrm{cm}^{3}$ to $3.08 \mathrm{~g} / \mathrm{cm}^{3}$. The threshold diameter and the average of the capillary decreased slightly. The percentage of the pores changed significantly (Tab. 3, Fig. 3) where pores of the range $25-10 \mu \mathrm{m}$ decreased from $49 \%$ to $38 \%$, pores of the range $10-1 \mu \mathrm{m}$ increased slightly from $29 \%$ to $30 \%$, and pores in the range of $1.0-0.1 \mu \mathrm{m}$ increased from $15 \%$ to $25 \%$. 

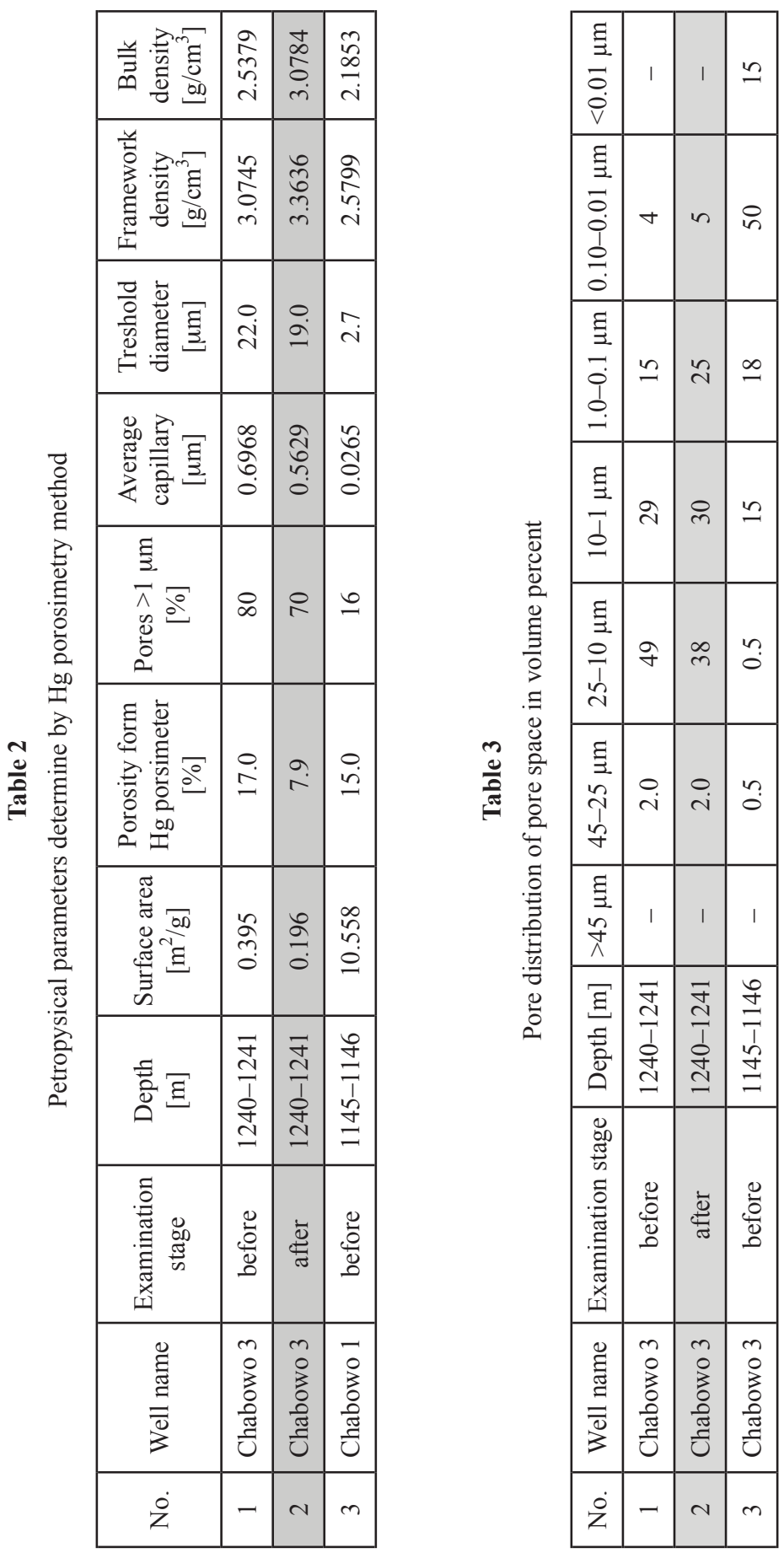


\section{Petrology-mineralogical analysis}

\section{Claystones}

The cap rock is represented by sandy mudstone with aleuritic-pelitic texture and layered structure. The individual layers differ from each other in grain size. There is a layer of coarser grains (grain size up to 150 microns, i.e. less than or equal as in very fine sand) and another finer-grained (grain size less than 30 microns, i.e. less than or equal as in medium silt). Elongated pores of different sizes occur in the rock. Their length sometimes reaches $6 \mathrm{~mm}$. Also a number of fractures are observed.

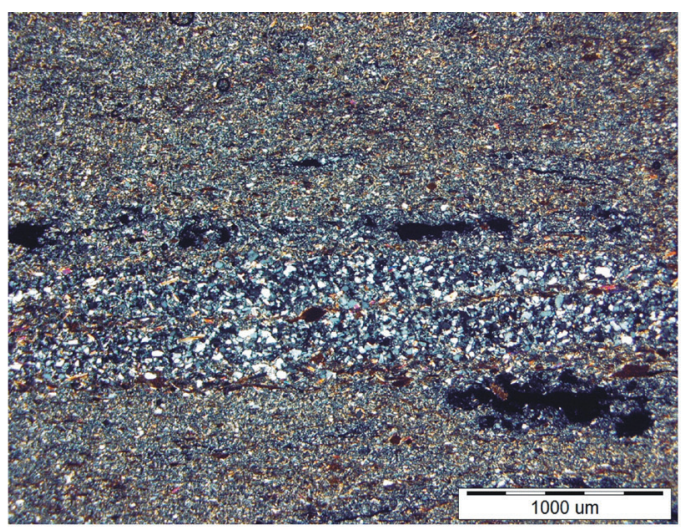

Observation in transmitted light of claystone before the expermient

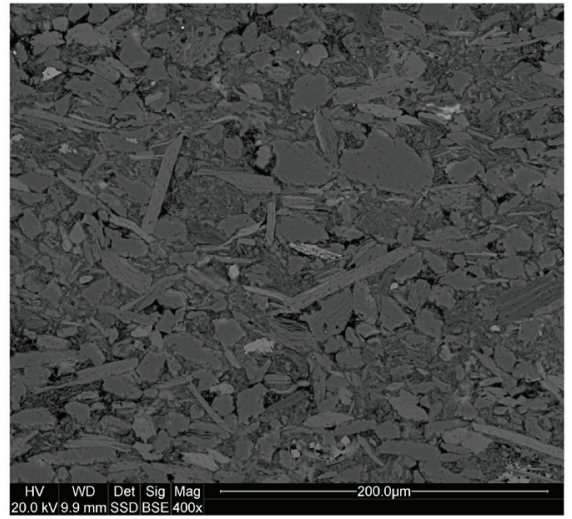

SEM microphotograph of claystone before the experiment

Fig. 4. Results of observation in transmitted light and SEM for claystone before the experiment

The analyzes of SEM-EDS, observations of mineral composition in transmitted light (Fig. 4) and XRD (Fig. 5), have shown that the dominant mineral is quartz. Mica and clay minerals (kaolinite, illite, montmorillonite, and chlorite) were observed as well. Carbonates are subordinate. Quartz grains are poorly rounded. Mica is represented by muscovite (often kaolinitization is observed) and biotite, which sometimes turns into chlorite. In addition, the claystone contains oxides and/or hydroxides of iron and opaque minerals. They form grains of various sizes irregularly scattered in the rock. Lithoclasts of fine quartz and micas were also observed.

As a result of the experiment changes in the rock were observed only in the XRD analysis of the separated clay fraction (Fig. 6), where the diffraction curve after the experiment did not show reflections generated by montorillonite and chlorite. 


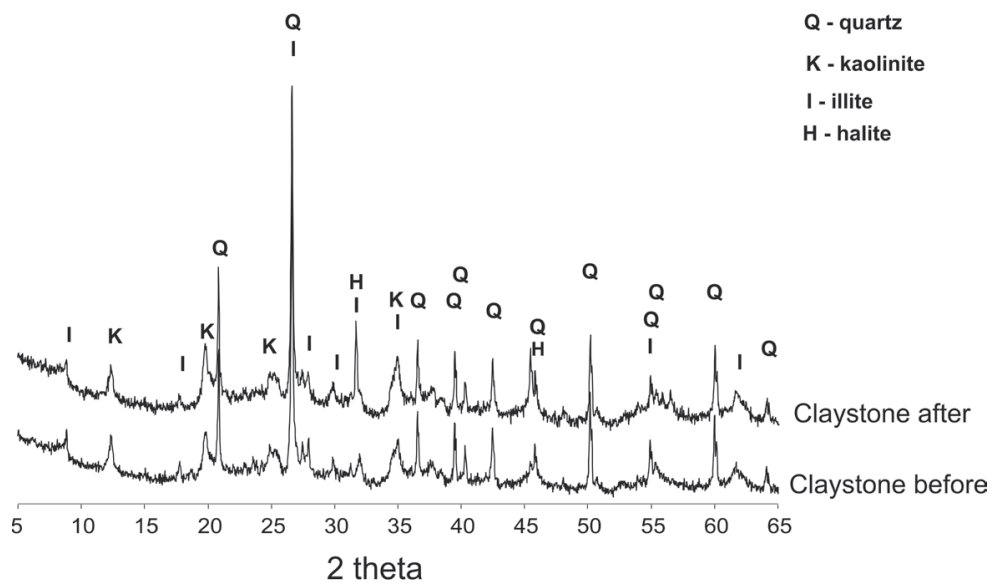

Fig. 5. XRD diffraction patterns of clay before and after the experiment
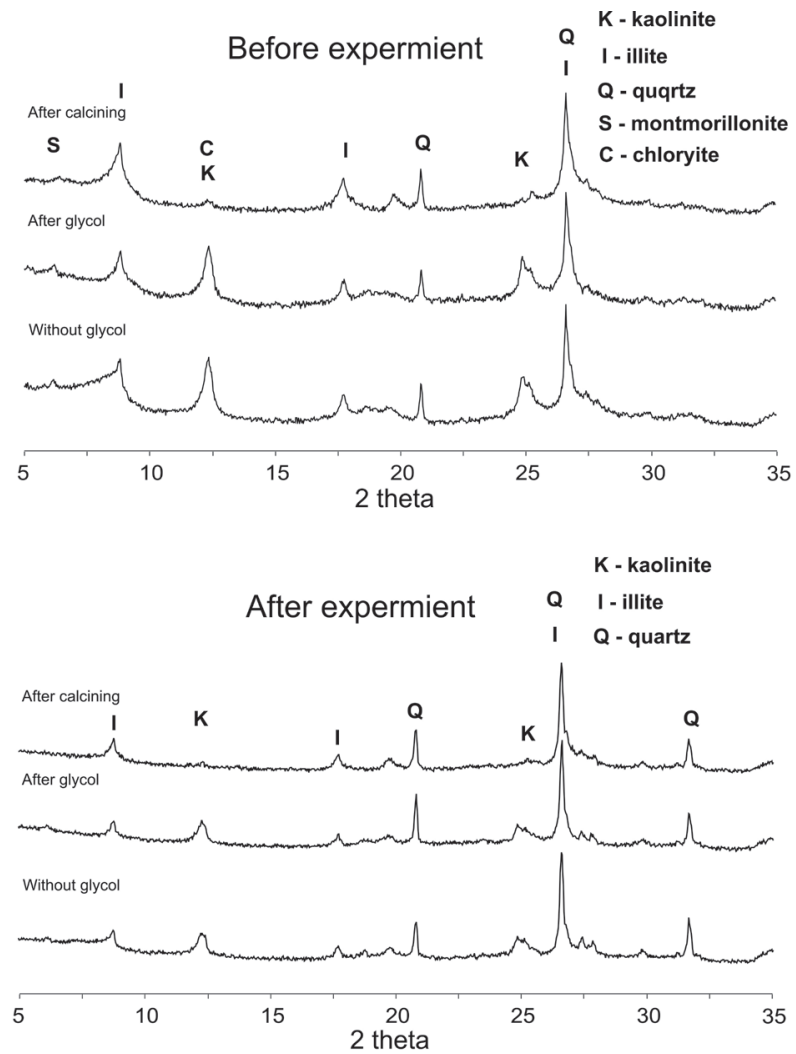

Fig. 6. XRD diffraction patterns of clay fraction separated form claystone before and after the experiment 


\section{Sandstones}

The petrological-mineralogical (Figs 7,8) analysis has shown that the rock sample is represented by medium and fine grained sandstone of psammitic texture. It is relatively porous with pore size up to 500 microns. Frameworks grains are mainly represented by quartz and feldspar (planimetric analysis is show in the Table 4); mica, lithoclasts, amphibole occur in subordinate amounts.

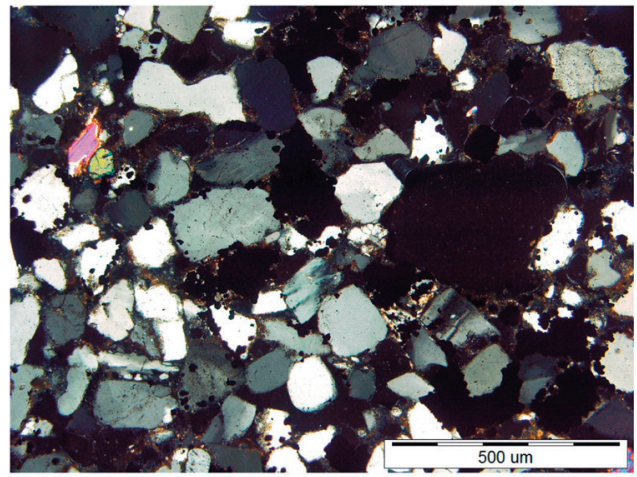

Observation in transmitted light of sandstone before the experiment

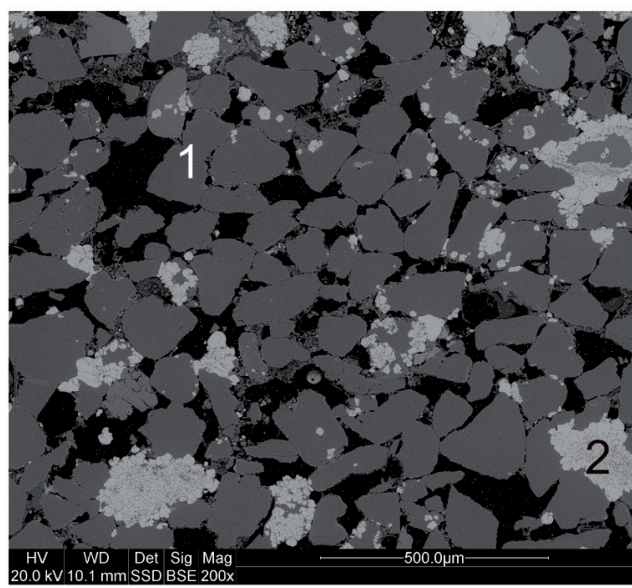

SEM microphotograph of sandstone before the experiment, magnification $200 \times ; 1$ - quartz, 2 - pyrite

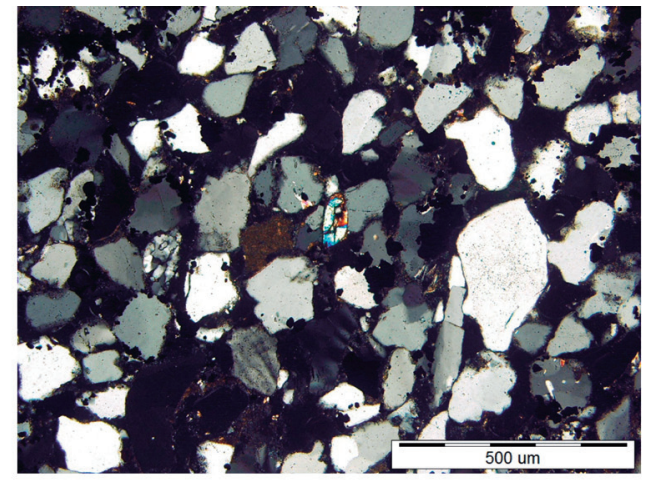

Observation in transmitted light of sandstone after the experiment

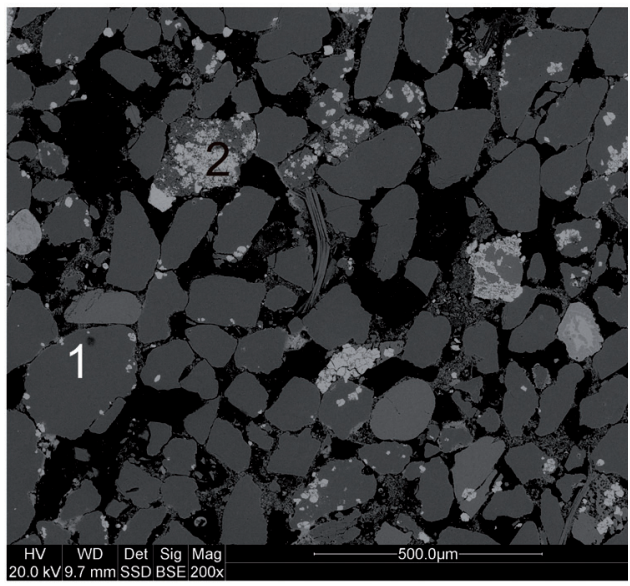

SEM microphotograph of sandstone after the experiment, magnification $200 \times ; 1$ - quartz, 2 - pyrite

Fig. 7. Results of observation in transmitted light and SEM for sandstone before and after the experiment 
Accessory minerals are represented by zircon, apatite and opaque minerals. Also rutile and titanite is observed. Rocks is cemented mainly by carbonate (matrix, composed mainly of siliceous detritus occurs occasionally). In pore spaces finely formed kaolinitic worms are observed (SEM-EDS analysis).

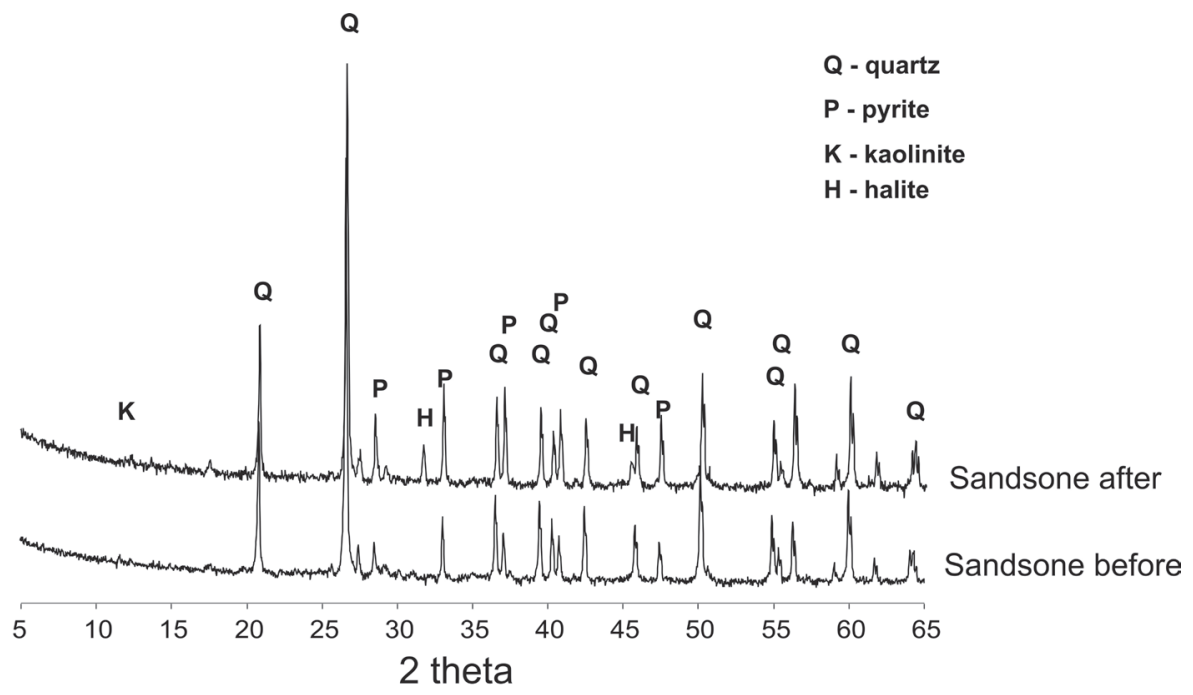

Fig. 8. XRD diffraction patterns of sandstone before and after the experiment

Table 4

Planimetric analysis before and after the experiment

\begin{tabular}{|c|c|c|}
\hline Components & Share before experiment [\% vol.] & Share after experiment [\% vol.] \\
\hline quartz & 44.6 & 42.0 \\
\hline feldspars & 9.6 & 8.6 \\
\hline micas & 0.8 & 0.8 \\
\hline opaque minerals (pyrite) & 14.4 & 17.4 \\
\hline lithoclasts & 0.4 & 0.4 \\
\hline pores & 16.4 & 19.8 \\
\hline cement & 11.4 & 8.8 \\
\hline matrix & 1.2 & 0.8 \\
\hline others & 1.2 & 1.4 \\
\hline (zircon, apatite, rutile, tytanite) & 100.0 & 100.0 \\
\hline
\end{tabular}


Characteristics of individual mineral grains:

- Quartz - is represented by poorly roundness grains. There are also grains of heavily fractured quartz, creating a fine mosaic. The quartz grains have sometimes minor inclusions of opaque minerals and micas.

- Feldspars - are represented both by potassium feldspars (among others microcline), revealing two systems of twinning: albitic (010) and pericline (001), and also by plagioclases showing the polysynthetic twinning. Sometimes these minerals are highly fractured and occasionally sericitization is seen. Minor inclusions of opaque minerals in feldspars are often observed.

- Micas - occur in small amounts, including mainly muscovite; biotite is very rare. Mica creates small, individual flakes, sometimes broken and twisted and weathered. They are found also in the form of small inclusions in quartz.

- Lithoclasts - are individual fragments of older rocks, represented mostly by quartzite.

- Amphiboles - form single, rounded grains green-yellowish in color.

- Accessory minerals - are represented by zircon, apatite and opaque minerals and rutile and titanite. The opaque minerals are predominant, among which mainly occur pyrite (present in relatively large amounts). They form irregular grains of different sizes of up to 300 microns. Zircon is in the form of automorphic bars and reaches a maximum size of about 150 microns. Apatite also forms automorphic bars and occurs mostly as inclusions in quartz.

\section{Analysis of the brine}

The analyses of brines (Tab. 5) show an increase in mineralization of both reservoir and cap rocks after the experiment, which resulted from dissolution of the rock matrix and the cements.

Table 5

Results of brines analysis

\begin{tabular}{|c|c|c|c|c|}
\hline Characteristics & Units & $\begin{array}{c}\text { Content in the } \\
\text { brine sample before } \\
\text { experiment }\end{array}$ & $\begin{array}{c}\text { Content in the brine } \\
\text { with sandstones after } \\
\text { the experiment }\end{array}$ & $\begin{array}{c}\text { Content in the brine } \\
\text { with cap rocks after } \\
\text { the experiment }\end{array}$ \\
\hline bulk density & $\mathrm{g} / \mathrm{ml}$ & 1.0586 & 1.0647 & 1.0637 \\
\hline mineralization & $\mathrm{g} / \mathrm{l}$ & 85.526 & 93.126 & 92.738 \\
\hline chlorides & $\mathrm{mg} / 1 \mathrm{Cl}^{-}$ & 50,700 & 54,155 & 56,548 \\
\hline sulphates & $\mathrm{mg} / 1 \mathrm{SO}_{4}^{2-}$ & 728 & 2745 & 957 \\
\hline hydrocarbons & $\mathrm{mg} / \mathrm{l} \mathrm{CO}_{3}^{-}$ & 110 & 788 & 474 \\
\hline
\end{tabular}


Table 5 cont.

\begin{tabular}{|c|c|c|c|c|}
\hline calcium & $\mathrm{mg} / \mathrm{l} \mathrm{Ca}^{2+}$ & 1,178 & 2,152 & 1,130 \\
\hline magnesium & $\mathrm{mg} / 1 \mathrm{Mg}^{2+}$ & 164 & 246 & 418 \\
\hline sodium & $\mathrm{mg} / 1 \mathrm{Na}^{+}$ & 29,500 & 33,700 & 34,100 \\
\hline potassium & $\mathrm{mg} / 1 \mathrm{~K}^{+}$ & 211 & 323 & 387 \\
\hline
\end{tabular}

In case of brine from the sandstone reservoir the contents of sulphates essentially increases, which is probably related to dissolution of pyrite. Dissolution of sandstones and claystones is also shown by an increase of calcium (in the case of sealing rock, the significant increase after the experiment indicates the presence of carbonate cements in the rock matrix), magnesium, sodium and potassium ions (in case of cap rocks increase of these ions can be related to dissolution of clay minerals). The significant increase in the content of hydrocarbons is mainly due to dissolution of $\mathrm{CO}_{2}$ in the brine.

\section{DISCUSSION}

Long-term (20-month) experiment of interactions between brine, rock and $\mathrm{CO}_{2}$ was to determine the effect of injected $\mathrm{CO}_{2}$ on petrophysical and petrological-mineralogical parameters on the analyzed reservoir and its cap rocks.

In the case of reservoir rocks (sandstone) petrophysical results have shown significant decrease in porosity from $17 \%$ to $7.9 \%$, which may be associated with precipitation of mineral phases in the pore spaces. However, the mineralogical analysis (planimetric analysis) shows a slight increase in porosity of $16.4 \%$ to $19.4 \%$, which indicates dissolution of the mineral phase which confirms the decrease of the percentage of feldspars (from $9.6 \%$ to $8.6 \%$ ) and total cement (from $12.6 \%$ to $9.6 \%$ ).

Dissolution is also confirmed by an increase of sulfate ions as well as calcium, sodium, potassium and magnesium in the brine after the experiment. In addition, the increase of pyrite content in the rock was observed after the experiment, which may indicate probable precipitation of this mineral as a result of the experiment. Similar results were obtained by Znahg et al. (2011). However, in order to distinguish the genesis of pyrite more detailed studies should be carried out.

The controversial results of porosity after the experiment (different from the method of porosimetry analysis and different from planimetric analysis) could indicate the heterogeneity of the analyzed rocks, because the discussed studies were not performed on exactly the same rock samples, but only on the specimens that represented the same depth interval. However, the heterogeneity is precluded by similar porosity values from the planimetric analysis and $\mathrm{Hg}$ porosimetry for samples before the experiment. Therefore, we can assume that halite was precipitated in pore spaces as a result of interactions between brine, rock and $\mathrm{CO}_{2}$, which is confirmed by the data of XRD and SEM-EDS of 
the entire area of the analyzed sample. Therefore, planimetric analysis results are more reliable, since the formulation halite was eluted from the pore spaces during preparation of thin sections.

In the case of cap rocks (claystone), where the rock has disintegrated into pieces as a result of the experiment, we can conclude that the rock is too poorly compacted, therefore, can not constitute the seal for $\mathrm{CO}_{2}$ storage activities. In addition, changes in the composition of the clay fraction were observed whereby after the experiment there is no montorillonite and chlorite left, which were observed before. It should be borne in mind that the analyzed rocks were collected from the borehole core archives where they were stored for many years. So the determination of these parameters probably does not reflect reality. Therefore, it is desirable to carry out geochemical modeling as supplementary examinations, because this approach is of great importance considering the assessment of suitability of geological structures for $\mathrm{CO}_{2}$ sequestration (Labus et al. 2010).

The studies represent only basic research, i.e. they constitute one of the steps towards estimating the suitability of potential structures for the $\mathrm{CO}_{2}$ storage. Therefore, should be supplemented by additional analysis of petrophysical studies of permeability (which, due to the low amount of rock analyzed in this project, was not possible) and geochemical modelling of long-term storage of $\mathrm{CO}_{2}$.

\section{CONCLUSIONS}

Based on the results obtained in the course of laboratory experiment on interaction between $\mathrm{CO}_{2}$, brine and rocks the following can be concluded:

- samples before petrophysical investigation should be rinsed in order to avoid precipitation of halite in pore spaces;

- petrological-mineralogical investigation of thin section is the most reliable examination of $\mathrm{CO}_{2}$-brine-rock interactions in the light of the presented work;

- the Chabowo anticline selected for $\mathrm{CO}_{2}$ sequestration should be investigated in a more detailed manner in order to assess its usefulness to CCS operation.

The project was funded by the National Science Centre, through research grant allocated according to the decision no. DEC-2011/03/B/ST10/04340.

\section{REFERENCES}

Birkholzer J.T. \& Zhou Q., 2009. Basin-scale hydrogeologic impacts of $\mathrm{CO}_{2}$ storage: capacity and regulatory implications. International Journal of Greenhouse Gas Control, 3, 6, $745-756$.

Fischer S., Liebscher A., Wandrey M. \& the CO2SINK Group, 2010. $\mathrm{CO}_{2}$-brine-rock interaction - First results of long-term exposure experiments at in situ P-T conditions of the Ketzin $\mathrm{CO}_{2}$ reservoir. Chemie der Erde/Geochemistry, 70, S3, 155-164. 
Gaus I., Azaroual M. \& Czernichowski-Lauriol I., 2005. Reactive transport modelling of the impact of $\mathrm{CO}_{2}$ injection on the clayey caprock at Sleipner (North Sea). Chemical Geology, 217, 319-337.

Gunter W.D., Perkins E.H. \& Hutcheon I., 2000. Aquifer disposal of acid gases: modelling of water-rock reactions for trapping of acid wastes. Applied Geochemistry, 15, 8, 1085-1095.

Gunter W.D., Perkins E.H. \& Mccann T.J., 1993. Aquifer disposal of $\mathrm{CO}_{2}$-rich gases reaction design for added capacity. Energy Conversion and Management, 34, 941-948.

IPCC, 2005. Special report of the intergovernmental panel on climate change on carbon dioxide capture and storage [Metz B., Davidson O., de Coninck H.C., Loos M., Meyer L.A. (eds.)]. New York.

IPCC, 2007. Climate Change 2007. Synthesis Report. Contribution of Working Groups I, II and III to the Fourth Assessment Report of the Intergovernmental Panel on Climate Change [Core Writing Team, Pachauri R.K \& Reisinger A. (eds)]. IPCC, Geneva, Switzerland.

Labus K., 2009. Modeling hydrochemical effects of carbon dioxide sequestration in saline aquifer of the upper Silesian coal basin. Wydawnictwo Politechniki Śląskiej, Gliwice.

Labus K., Wdowin M. \& Tarkowski R., 2010. Assessment of $\mathrm{CO}_{2}$ sequestration capacity based on hydrogeochemical model of Water-Rock-Gas interactions in the potential storage site within the Bełchatów area (Poland). Gospodarka Surowcami Mineralnymi - Mineral Resources Management, 26, 2, 69-84.

Muller N., Qib R., Mackiea E., Pruessc K. \& Blunt M.J., 2009. CO injection impairment due to halite precipitation. Energy Procedia, 1, 1, 3507-3514.

Pang Z., Kong Y., Li Y. \& Li J., 2013. Water-rock interaction in $\mathrm{CO}_{2}$ sequestration in a depleted oil reservoir pilot test. Procedia Earth and Planetary Science, 7, 656-659.

Pettijohn F.J., Potter P.E. \& Siever R., 1972. Sand and sandstone. Springer-Verlag, New York.

Soong Y., Goodman A.L., McCarthy-Jones J.R. \& Baltrus J.P., 2004. Experimental and simulation studies on mineral trapping of $\mathrm{CO}_{2}$ with brine. Energy Conversion and Management, 45, 11-12, 1845-1859.

Tarkowski R. (red.), 2010. Potencjalne struktury geologiczne do składowania $\mathrm{CO}_{2}$ w utworach mezozoiku Niżu Polskiego (charakterystyka oraz ranking) [Potential geological structures to $\mathrm{CO}_{2}$ storage in the Mesozoic Polish Lowlands (characteristics and ranking)]. Studia, Rozprawy, Monografie 164, IGSMiE PAN, Kraków.

Tarkowski R. \& Wdowin M., 2011. Petrophysical and Mineralogical Research on the Influence of $\mathrm{CO}_{2}$ Injection on Mesozoic Reservoir and Caprocks from the Polish Lowlands. Oil \& Gas Science and Technology - Revue d'IFP Energies nouvelles, 66, 1, 137-150.

Wdowin M., Tarkowski R. \& Manecki M., 2013. Petrographic-mineralogical and textural changes in reservoir and sealing rocks (Zaosie anticline) as a result of a long-term experiment in CO2-brine-rock interactions. Gospodarka Surowcami Mineralnymi-Mineral Resources Management, 29, 4, 137-154. 
Wdowin M., Tarkowski R. \& Franus W., 2014. Supplementary studies of textural and mineralogical changes in reservoir and cap rocks from selected potential sites suitable for underground $\mathrm{CO}_{2}$ storage. The Arabian Journal for Science and Engineering, 39, 1, 295-309.

Zeidouni M., Pooladi-Darvish M. \& Keith D., 2009. Analytical Solution to Evaluate Salt Precipitation during $\mathrm{CO}_{2}$ Injection in Saline Aquifers. Energy Procedia, 1, 1, 1775-1782. Zhang W., Xu T. \& Li Y., 2011. Modeling of fate and transport of Co-injection of $\mathrm{H}_{2} \mathrm{~S}$ with $\mathrm{CO}_{2}$ in deep saline formations. Journal of Geophysical Research, 116, B02202. 